\title{
Assessment of the activity of a fructo-oligo- saccharide on different caecal parameters in rabbits experimentally infected with $E$ coli 0.103
}

\author{
JP Morisse, R Maurice, E Boilletot, JP Cotte \\ Centre National d'Études Vétérinaires et Alimentaires, BP 53, 22440 Ploufragan, France
}

(Received 28 June 1992; accepted 24 August 1992)

\begin{abstract}
Summary - Thirty 51-d-old rabbits, fed since the 18th $d$ on a mixed diet containing a fructo-oligosaccharide (FOS) added at $0.25 \%$ (FOS group) and 30 51-d-old rabbits without FOS (C group) were infected via oesophagal route, with $2 \times 10^{7} \mathrm{E}$ coli 0.103 strain $\mathrm{B}_{10}$. Seven d after challenge the first digestive symptoms were observed, and $20 \%$ of the animals died in each group; in the survivors, the number of rabbits without any clinical signs was significantly higher in the FOS group $(35.7 \%$ versus $14.8 \%$ in the $C$ group $P<0.05$ ). In the FOS group the body weights of survivors were $95 \mathrm{~g}$ more than the controls weights (2 $454 \mathrm{~g}$ versus $2359 \mathrm{~g}$ ). At $80 \mathrm{~d}, 14$ animals were euthanised in each group and different caecal parameters were compared. In the FOS group the following were observed:

- a lower $\mathrm{pH}: 6.04$ versus $6.26(P<0.05)$;

- a strong rise in total VFA: $73.4 \mathrm{mmol} / \mathrm{kg}$ versus $56.2 \mathrm{mmol} / \mathrm{kg}(P<0.05)$;

- a marked decrease of $\mathrm{NH}_{3}: 11.1 \mathrm{mmol} / \mathrm{kg}$ versus $17.0 \mathrm{mmol} / \mathrm{kg}(P<0.001)$;

- an increase in saprophytic $E$ coli counts: $10^{4.2} / \mathrm{g}$ versus $10^{2.5} / \mathrm{g}(P<0.001)$. The results confirm the possibility that FOS increases the rate of VFA production in the caecum. With this increase is associated a higher $E$ coli population $(P<0.001)$, characteristic of a favourable biochemical environment $\left(\mathrm{pH}, \mathrm{VFA}, \mathrm{NH}_{3}\right.$ ) and considered by the authors as able to reduce the morbidity (but not the mortality) induced by an enteropathogenic $E$ coli infection.
\end{abstract}

fructo-oligo-saccharide / caecal parameter / rabbit / colibacillosis

Résumé - Évaluation de l'activité d'un fructo-oligo-saccharide sur différents paramètres cæcaux chez le lapin soumis à une colibacillose expérimentale. Trente lapereaux de $51 j$ ayant reçu depuis le $18^{\circ} \mathrm{j}$ un aliment contenant $0,25 \%$ d'un fructo-oligo-saccharide (FOS) et 30 lapereaux recevant un aliment témoin (C) ont reçu par voie cesophagienne $2 \times 10^{7} \mathrm{E}$ coli 0103 souche $B 10$. Sept jours après l'épreuve expérimentale, les premiers troubles digestifs apparurent et les pertes furent équivalentes dans les deux lots (20\%); cependant, chez les survivants, le nombre de sujets n'ayant extériorisé aucun trouble digestif a été significativement plus élevé dans le lot FOS $135,7 \%$ versus $14,8 \%$ pour le lot témoin $P<0,05$ ). $\dot{A} J 80,14$ sujets dans chaque lot ont été sacrifiés et des contrôles ont été réalisés sur différents paramètres cæcaux. Chez les sujets du lot FOS ont été observés : un pH cæcal plus faible : 6,04 versus 6,26 (P<0,05); une élévation du taux de $A G V: 73,4$ $\mathrm{mmol} / \mathrm{kg}$ versus $56,2 \mathrm{mmol} / \mathrm{kg}(\mathrm{P}<0,05)$; une diminution de l'ammoniac : $11,1 \mathrm{mmol} / \mathrm{kg}$ versus 17,0 $(\mathrm{P}<0,001)$; une augmentation de la densité des colibacilles non pathogènes $10^{4,2} / \mathrm{g}$ versus $10^{2,5} \mathrm{~g}$ 
( $\mathrm{P}<0,001)$. Ces résultats confirment l'aptitude du fructo-oligo-saccharide étudié à augmenter la production des AGV au niveau du cæcum. À cette augmentation du taux des AGV est associé, dans les conditions de l'étude, un développement significatif de la flore colibacillaire $(P<0,001)$. Les auteurs émettent l'hypothèse que le niveau atteint par la flore colibacillaire dans un environnement biochimique favorable ( $p H, A G V, N H 3$ ), permet de limiter la morbidité (mais non la mortalité) liée à une infection expérimentale par un colibacille entéropathogène.

fructo-oligo-saccharide / paramètre cæcaux / colibacillose

\section{INTRODUCTION}

The prevention of enteritis is of utmost economic importance for rabbit producers as intestinal troubles are responsible for average losses of $\approx 12 \%$ of animals between the ages of weaning and slaughtering (Koel, 1991).

The intensive use of antibiotics to prevent or control enteritis has many disadvantages such as poor efficiency, risks of antibioresistance and residues left in the meat.

An anarchistic development of enteropathogenic $E$ coli $(0.103,0.15)$ and/or Clostridia (mainly $C$ spiroforme) (Carman and Borriello; Renault et al, 1983; Milon et al, 1990; Peeters and Geeroms, 1991) due to various causes such as stress, inadequate diet or intolerance to different antibiotics (Morisse et al, 1979, 1985) is commonly observed in enteritis.

As dysbacteriosis is usually related to a severe reduction of volatile fatty acids (VFA) in the caecum, to a strong rise in caecal ammonia and to a rise in the $\mathrm{pH}$ (Prohaszka, 1980), the prevention of enteritis has been attempted either by direct acidification of the intestinal content (Morisse et al, 1979) or by providing the animals with a suitable glucide balance (cellulose and starch) in order to induce high levels of VFA in the intestine (Morisse et al, 1985).

In a previous study (Morisse et al, 1990) we have shown that several parameters in the caecum, ie $\mathrm{pH}$, VFA, ammonia) could be modulated by the utilization of a mixture of fructo-oligo-saccharides (FOS) (Profeed, ${ }^{\circledR}$ Beghin-Meiji Industries).

FOS are non hydrolysable compounds of glucose $(G)$ and fructoses $(F)$, eg $G F_{2}$, $\mathrm{GF}_{3}, \mathrm{GF}_{4}$, etc (Takahisa et al, 1989). They exist naturally in many kinds of plants such as onions, asparagus roots, bananas, etc and are industrially obtained from sucrose by enzymatic action of $\beta$-fructofuranosidase from Aspergillus niger.

In human intestinal flora, the selective utilization of FOS by intestinal bacteria leads to a remarkable increase in bifidobacteria, a reduction of Clostridium perfringens and of putrefaction products; and the rate of VFA also rises markedly (Hidaka, 1986).

The aim of the present study was to try to reproduce the caecal modifications already observed in rabbits and to test the resistance of these FOS-treated animals to an experimental infection with an enteropathogenic $E$ coli 0.103 .

\section{MATERIAL AND METHODS}

\section{Determination of the infective dose and of the age of the challenged animals}

The setting up of the experimental model required several experimentations with the aim of determining the adequate infective concentration of $E$ coli $0.103 \mathrm{~s} . \mathrm{B}_{10}$ and the age of opti- 
mum susceptibility required to induce a mediumintensity rate of mortality-morbility.

A preliminary trial (see Annex) involving 4 groups of 10 37-d-old rabbits: 1 non inoculated control and 3 groups respectively inoculated with $2 \times 10^{4} 2 \times 10^{5}$ and $2 \times 10^{6} \mathrm{E}$ coli, resulted in a mortality rate not exceeding $1 / 10$ in any group within an observation period of $17 \mathrm{~d}$.

A second experiment performed in 4 groups of 37-d-old animals, inoculated under identical conditions gave similar results.

In addition, higher infective doses $\left(10^{8}\right.$ and $10^{9} \mathrm{E}$ coli) were tested in 2 groups of 6 rabbits. The mortality rates were respectively 2 and 3 animals and the morbidity (number of $d$ of enteritis) ranged linearly in function of the dose from $10^{4}-10^{9}$ (see Annex).

In spite of the similarity of the experimental design, the susceptibility of our rabbits under our feeding conditions was demonstrated to be much lower than that of animals used by Licois et al (1990).

A third experiment performed with an infective dose of $2 \times 10^{7} \mathrm{E}$ coli in 1837 -d-old and in 18 51-d-old rabbits demonstrated that under our conditions, mortality and morbility were lower at $37 \mathrm{~d}$ than at $51 \mathrm{~d}$ of age (see Annex).

From these preliminary adjustments (summarized in the Annex) the experimental conditions were determined as follows: age: $51 \mathrm{~d}$, infective dose: $2 \times 10^{7}$ E coli $0.103 \mathrm{~s} \mathrm{~B}_{10}$.

\section{Animals, housing and diet}

Thirty 51-d-old rabbits fed since the 18th $d$ on a mixed diet containing Profeed, a FOS compound (FOS group) and 30 51-d-old rabbits receiving the same diet without FOS (C group), were housed 6 per cage in an absolute air filtered chamber $(0.22 \mu \mathrm{m})$ for $29 \mathrm{~d}$.

FOS was added to the basic diet (table I) at the rate of $0.25 \%$ of a specific mixture of $\mathrm{GF}_{2}$, $\mathrm{GF}_{3}$ and $\mathrm{GF}_{4}(0.7 \%$ Profeed).

\section{Challenge}

On the day after their transfer to the air-filtered chamber, each animal was infected via oesophagal route with $2 \times 10^{7} \mathrm{E}$ coli 0.103 strain $\mathrm{B}_{10}$ cultivated in trypticase-soya medium.

\section{Recordings}

The animals were observed daily for abnormalities and the growth of survivors was controlled by individual weighings at $\mathrm{d} 51$ and 80 .

Dead animals were autopsied and attempts made to recover $E$ coli 0.103 by serotyping.

Table 1. Composition and analytical characteristics of the diet.

\begin{tabular}{lclr}
\hline Ingredients & $\%$ & Analysis & $\%$ \\
\hline Alfalfa 17 & & & \\
Wheat bran & 25.5 & Dry matter & 87.4 \\
Oats & 25.5 & Crude protein & 15.9 \\
Wheat & 14.5 & Fat & 4.7 \\
Soya 48 meal & 7 & Fiber & 14.2 \\
Sunflower meal & 6 & Neutral deterg fiber & 32.1 \\
Citrus meal & 5.5 & Acid deterg fiber & 17.8 \\
Cocoa hull & 2.5 & Lignin & 4.8 \\
Wheat straw & 2.5 & Starch & 15.5 \\
Soya oil & 2 & Soluble sugars & 5.4 \\
Sugar & 1.5 & Digestible energy & 2580 \\
Corn gluten & 1.5 & Kcal/kg & \\
Mineral-vitamin mixture & 1 & & \\
\hline
\end{tabular}


At d 80,14 animals from each groups were selected on the basis of the visible absence of any signs of enteritis; the animals were killed and the following caecal investigations were carried out: measurement of $\mathrm{pH}$ (electrode of the pHmeter inserted into the caecum); amount of VFA and ammonia (gas chromatography); $E$ coli count in $\mathrm{Na}$ desoxycholate plate medium.

\section{Statistical analysis}

Mortality, morbidity and biochemical results were compared using the $\chi^{2}$ test.

\section{RESULTS AND DISCUSSION}

\section{Sanitary results}

As a consequence of the inoculation by the oesophagal route, 5 animals died or were eliminated within the first $2 \mathrm{~d}$ after challenge. Observations were performed respectively on 28 rabbits for the $C$ group and $\mathbf{2 7}$ for the FOS group. Results are given in table II.

\section{Mortality}

Five animals in group $C$ and 6 animals in the FOS group died with clinical signs of enteritis during the observation period.
At post-mortem examination there was evidence of acute typhlitis and $E$ coli 0.103 was recovered from caecal liquid contents.

Neither the mortality rate (18 and $22 \%$ ) nor the course of the disease in the dead animals differed between the 2 groups.

On average, the first clinical signs appeared at the 7th $d$ post-challenge and mortality occurred 5-7 d after an acute diarrhoea.

\section{Morbidity}

Among the surviving rabbits, the number of animals exhibiting clinical signs of diarrhoea was statistically lower in the FOS group: $4 / 27(14.8 \%)$, compared with $13 / 28$ $(46.4 \%)$ in the group $\mathrm{C}(P<0.05)$ (table II).

\section{Weight gain of survivors}

In rabbits free of clinical signs, the mean body weight at $d 80$ in the FOS group was $95 \mathrm{~g}$ more than that in the group C: 2454 g compared with $2359 \mathrm{~g}$ respectively; but the difference was not significant (table III).

\section{Caecal parameters}

The tests performed on caecal contents at $80 \mathrm{~d}$ of age showed several statistically

Table II. Sanitary results.

\begin{tabular}{|c|c|c|c|c|c|c|c|}
\hline \multirow[t]{2}{*}{ Group } & \multirow{2}{*}{$\begin{array}{l}\text { No of } \\
\text { of animals } \\
\text { at } d 51\end{array}$} & \multicolumn{2}{|c|}{ Dead animals } & \multicolumn{2}{|c|}{ Animals with enteritis } & \multicolumn{2}{|c|}{ Animals without enteritis } \\
\hline & & No & $\%$ & No & $\%$ & No & $\%$ \\
\hline $\begin{array}{l}\text { C } \\
\text { FOS }\end{array}$ & $\begin{array}{l}28 \\
27\end{array}$ & $\begin{array}{l}5 \\
6\end{array}$ & $\begin{array}{l}17.9 \\
22.2\end{array}$ & $\begin{array}{l}13 \\
4^{\star *}\end{array}$ & $\begin{array}{l}46.4 \\
14.8\end{array}$ & $\begin{array}{l}10 \\
17\end{array}$ & $\begin{array}{l}35.7 \\
14.8\end{array}$ \\
\hline
\end{tabular}

$\because P<0.01$. 
significant differences between the 2 groups (table IV). The FOS group had:

- a lower pH: 6.04 versus $6.26(P<0.05)$;

- a higher rate of VFA production: 73.4 $\mathrm{mmol} / \mathrm{kg}$ of crude material versus $\mathbf{5 6 . 2}$ $\mathrm{mmol} / \mathrm{kg}(P<0.05)$;

- a marked decrease in ammonia production: $11.1 \mathrm{mmol} / \mathrm{kg}$ versus $17.0 \mathrm{mmo} / \mathrm{kg}$ $(P<0.001)$;

- an increase in saprophytic $E$ coli counts: $10^{4.2 / g}$ versus $10^{2.5} / \mathrm{g}(P<0.001)$ and a more regular distribution of $E$ coli within the FOS group.

The data recorded in the FOS group were characteristic of healthy rabbits whereas in the group $\mathrm{C}, \mathrm{pH}$, ammonia and VFA rates were representative of critical values.

In digestive disorders, several changes are routinely observed in caecal content: a rise in $\mathrm{pH}$ (up to 7) a marked development of $E$ coli (107-109/g) a rise in ammonia levels and a drop in VFA production rate $(40-45 \mathrm{mmol} / \mathrm{kg}$ versus 70 80 mmol.kg).

Rabbits are generally considered as differing from all the other species as far as $E$ coli counts are concerned: while $E$ coli counts in the caecal contents are $\approx 105 / \mathrm{g}$ in most species under normal conditions, practically no $E$ coli occur in healthy rabbits (Smith and Crabb, 1961; Prohaszka, 1980). In fact, from our previous studies on feeding and intestinal environment (Morisse et al, 1985, 1990) we are of the opinion that the limited $E$ coli population or its absence in many animals is not physiological but is the consequence of a relative inadequacy of intensive feed on the digestive physiology of rabbits. The abnormally small $E$ coli population could explain

Table III. Growth of survivors without clinical signs.

\begin{tabular}{lccccc}
\hline Group No d51 & $\begin{array}{c}\text { Body weight }(g) \\
d 51\end{array}$ & $\begin{array}{c}\text { No of healthy } \\
\text { rabbits } \\
d 80\end{array}$ & $\begin{array}{c}\text { Body weight } \\
d 80 \\
(g)\end{array}$ & $\begin{array}{c}\text { Average } \\
\text { daily gain } \\
(g / d)\end{array}$ \\
\hline C & 28 & $1478 \pm 108$ & 10 & $2359 \pm 156$ & $32.6 \pm 4.3$ \\
FOS & 27 & $1477 \pm 131$ & 17 & $2454 \pm 216$ & $33.5 \pm 17$ \\
\hline
\end{tabular}

Table IV. Summary of changes observed in the caecal contents.

\begin{tabular}{|c|c|c|c|c|c|c|c|c|}
\hline \multirow[t]{2}{*}{ Group } & \multirow{2}{*}{$\begin{array}{c}\text { No of } \\
\text { animals }\end{array}$} & \multirow[t]{2}{*}{$p H$} & \multirow{2}{*}{$\begin{array}{c}\text { E coli } \\
\left(\log _{10} / g\right)\end{array}$} & \multirow{2}{*}{$\begin{array}{c}\mathrm{NH}_{3} \\
\text { (mmolkg) }\end{array}$} & \multirow{2}{*}{$\begin{array}{l}\text { Total VFA } \\
\text { (mmol/kg) }\end{array}$} & \multicolumn{3}{|c|}{$V F A$ mmol/kg } \\
\hline & & & & & & $c_{2}$ & $c_{3}$ & $c_{4}$ \\
\hline $\begin{array}{l}\text { C } \\
\text { FOS }\end{array}$ & $\begin{array}{ll}14 & 6 \\
14 & 6\end{array}$ & $\begin{array}{l}6.26 \pm 0.31 \\
6.04 \pm 0.17^{*}\end{array}$ & $\begin{array}{l}2.5 \pm 0.3 \\
4.2 \pm 0.1^{\star \star * *}\end{array}$ & $\begin{array}{l}17.0 \pm 4.0 \\
11.1 \pm 3.4^{\text {t**}}\end{array}$ & $\begin{array}{l}56.2 \pm 24.8 \\
73.4 \pm 16.7^{\star}\end{array}$ & $\begin{array}{l}45.7 \pm 16.9 \\
57.6 \pm 13.0^{*}\end{array}$ & $\begin{array}{l}1.3 \pm 0.01 \\
1.8 \pm 0.01\end{array}$ & $\begin{array}{c}9.2 \pm 8.1 \\
19.8 \pm 4.9^{*}\end{array}$ \\
\hline
\end{tabular}

\footnotetext{
${ }^{*} P<0.05 ;{ }^{* *} P<0.001$.
} 
the extreme fragility of the intestinal flora balance and the increased opportunity for enteropathogenic $E$ coli to develop strongly.

In 'farmer rabbits' fed on vegetables and plants, and in wild rabbits, caecal $\mathrm{pH}$ are generally lower than in intensively fed rabbits: $5.6-5.8$ versus $6.2-6.5$ and $E$ coli counts are substantially higher: $10^{4}-10^{5} / \mathrm{g}$ versus $\leq 10^{2.5} / \mathrm{g}$ (Morisse et al, 1979, 1985).

In rabbits reared in this manner, enteritides of bacterial origin are not reported as having great significance.

The differences observed in $E$ coli counts between the 2 groups have been studied according to the sanitary status of animals after the experimental infection.

Although none of the rabbits presented any visible signs of enteritis when killed, 11 in the $C$ group had been recorded as sick animals versus only 3 in the FOS group.

Consequently, the increase observed in the $E$ coli counts in the latter group seems to be related to the FOS treatment and cannot be considered as a result of the disease; for this reason and in the absence of serotyping the increased $E$ coli counts can only be supposed to be non pathogenic.

We consider that all means (dietary balance or feed additive) whereby the biochemical characteristics of the caecal content are maintained in a steady state are a contribution towards the non therapeutic control of digestive pathologies in rabbits.

When biochemical parameters $(\mathrm{pH}$, VFA, ammonia) reach their optimum level, the Ecoli flora is more abundant than classically reported (Smith and Crabb, 1961); and although its level remains modest $(105 / \mathrm{g})$, it suggests a kind a barrier effect which prevents the development of pathogenic $E$ coli.

\section{CONCLUSIONS}

Under experimental conditions, the incorporation of a fructo-oligo-saccharide preparation (Profeed) in rabbit feed, partially reduced the pathogenic effect of $E$ coli 0.103 . In survivors, FOS allowed the restoration of several caecal parameters $(\mathrm{pH}$, $\mathrm{NH}_{3}$, VFA) to their proper physiological levels. The present work suggests that the physiological rise in the saprophytic $E$ coli population (barrier effect) could be of interest for the non-antibiotic control of bacterial enteritis. Nevertheless more research is necessary to determine the optimum dosage of FOS and to confirm the present results.

\section{ANNEX}

\section{Preliminary determination of the experimental conditions}

Experiment 1. Mortality and morbility observed in 4 groups of 10 37-d-old rabbits inoculated with $0,2 \times 10^{4}, 2 \times 10^{5}$ and $2 \times 10^{6} \mathrm{E}$ coli 0.103 strain $B_{10}$.

\begin{tabular}{lcccc}
$\begin{array}{l}\text { Infective } \\
\text { doses }\end{array}$ & $\begin{array}{r}\text { No of } \\
\text { animals }\end{array}$ & $\begin{array}{c}\text { No of dead } \\
\text { animals }\end{array}$ & $\begin{array}{c}\text { No of surviving } \\
\text { animals }\end{array}$ \\
\cline { 4 - 5 } & & & $\begin{array}{c}\text { With } \\
\text { enteritis }\end{array}$ & $\begin{array}{c}\text { Without } \\
\text { enteritis }\end{array}$ \\
\hline & & & & \\
0 (Control) & 10 & 1 & 0 & 9 \\
$2 \times 10^{4}$ & 10 & 1 & 2 & 7 \\
$2 \times 10^{5}$ & 10 & 1 & 3 & 6 \\
$2 \times 10^{6}$ & 10 & 1 & 5 & 4 \\
\hline
\end{tabular}


Experiment 2. Mortality and morbility recorded in 37-d-old rabbits infected with various doses of E coli 0.103 strain $B_{10}$.

\begin{tabular}{|c|c|c|c|}
\hline $\begin{array}{l}\text { Infective } \\
\text { doses }\end{array}$ & $\begin{array}{r}\text { No of } \\
\text { animals }\end{array}$ & $\begin{array}{l}\text { No of deac } \\
\text { animals }\end{array}$ & $\begin{array}{c}\text { No of surviving } \\
\text { animals }\end{array}$ \\
\hline & & & $\begin{array}{c}\text { With Without } \\
\text { enteritis enteritis }\end{array}$ \\
\hline
\end{tabular}

\begin{tabular}{lrrrr}
\hline 0 (Control) & 12 & 0 & 0 & 12 \\
$2 \times 10^{4}$ & 12 & 0 & 1 & 11 \\
$2 \times 10^{5}$ & 12 & 1 & 2 & 9 \\
$2 \times 10^{6}$ & 11 & 2 & 6 & 3 \\
$2 \times 108$ & 6 & 2 & 3 & 1 \\
$2 \times 109$ & 6 & 3 & 3 & 0 \\
\hline
\end{tabular}

Experiment 3. Mortality and morbility observed with a unique infective dose $\left(2 \times 10^{7} \mathrm{E}\right.$ coli 0.103 strain $B_{10}$ ) in 37 - and 51 -d-old rabbits.

\begin{tabular}{lcccc}
$\begin{array}{l}\text { Age } \begin{array}{c}\text { Age of } \\
\text { (d) }\end{array} \\
\text { animals }\end{array}$ & $\begin{array}{c}\text { No of dead } \\
\text { animals }\end{array}$ & \multicolumn{2}{c}{$\begin{array}{c}\text { No of surviving } \\
\text { animals }\end{array}$} \\
\cline { 3 - 5 } & & $\begin{array}{c}\text { With } \\
\text { enteritis }\end{array}$ & $\begin{array}{c}\text { Without } \\
\text { enteritis }\end{array}$ \\
\hline 37 & 18 & 2 & 4 & 12 \\
51 & 18 & 5 & 11 & 2 \\
\hline
\end{tabular}

\section{ACKNOWLEDGMENTS}

The authors are undebted to A Milon from the National Veterinary School of Toulouse for kindly supplying the $E$ coli 0.103 strain $B_{10}$.

\section{REFERENCES}

Carman RJ, Borriello SP (1982) Clostridum spiroforme isolated from rabbits with diarrhoea. Vet Rec 114, 461-462
Hidaka H (1986) Effects of fructo-oligosaccharides on intestinal flora and human health. Bifidobacteria Microflora 15 (1), 3750

Koel PF (1991) Gestion technico-économique : bilan et résultats 1990. Cuniculture 99, 18 (3), 129-137

Licois D, Guillot JF, Mouline C (1990) Sensibilité du lapin à une souche pathogène d'Escherichia coli 0,103 , effet de l'âge des animaux. In: $5^{\theta 5}$ Joumées de la Recherche Cunicole. 12-13 Dec 1990, Paris

Milon A, Camguilhem R, Esslinger J (1990) Vaccination du lapereau contre la colibacillose 0,103 : rôle de l'immunité anti LPS et de l'effet barrière exercée par des souches vivantes non pathogènes. In: $5^{e s}$ Joumées de la Recherche Cunicole. 12-13 Dec 1990, Paris

Morisse JP, Bodolec JL, Andrieux J, Le Floch B (1979) Essais de prévention d'une entérite colibacillaire chez le lapin par l'acide acétique, le lactulose et le lactose. Rec Méd Vét 155 (12), 943-954

Morisse JP, Boilletot E, Maurice R (1985) Alimentation et modification du milieu intestinal chez le lapin (AGV, $\mathrm{NH}_{3}, \mathrm{pH}$, flore). Rec Méd Vét 161 (5) 443-449

Morisse JP, Le Gall G, Maurice R, Cotte JP, Boilletot E (1990) Action chez le lapereau d'un mélange de fructo-oligo-saccharides sur certains paramètres intestinaux et plasmatiques. In : $5^{\text {es }}$ Joumées de la Recherche Cunicole. 12-13 Déc 1990, Paris

Peeters JE, Geeroms R (1991) Traitement et éradication de la colibacillose 0.15 sur le terrain. Cuniculture 101, 18 (5), 227-231

Prohaszka $L$ (1980) Antibacterial effect of volatile fatty acids in enteric $E$ coli infections of rabbits. Zbl Vét Méd 27, 631-639

Renault L, Roux J, De Bourhis E, Coudert P, Licois D, Guillot JF (1983) Description d'un sérogroupe $(0.103$ d' $E$ coli entéropathogène chez le lapin au sevrage. Bull Acad Vét Fr $56,387-400$

Smith N, Crabb NE (1961) The caecal flora of animals and men. J Pathol Bacteriol 82, 53, 53-66

Takahisa Tokunaga, Tsuneyuki Oku, Norimasa (1989) Utilisation and excretion of a new sweetener fructoligosaccharides (Neosugar) in rats. $J$ Nutr 199, 553-559 